Jelena Čulin, Ph.D.

E-mail: jculin@unizd.hr

Toni Bielić, Ph.D.

E-mail: tbielic@unizd.hr

University of Zadar, Maritime Department, Mihovila Pavlinovića 1, 23000 Zadar, Croatia

\title{
Plastic Pollution from Ships
}

\begin{abstract}
The environmental impact of shipping on marine environment includes discharge of garbage. Plastic litter is of particular concern due to abundance, resistance to degradation and detrimental effect on marine biota. According to recently published studies, a further research is required to assess human health risk. Monitoring data indicate that despite banning plastic disposal at sea, shipping is still a source of plastic pollution. Some of the measures to combat the problem are discussed.
\end{abstract}

Keywords: plastic pollution, marine environment, shipping, MARPOL 73/78 Annex V, education, environmental awareness

\section{Introduction}

Anthropogenic pollution poses a major threat to marine environment due to the harmful effect on biota, ecosystem structure and function. It also causes an economic, human health and aesthetic problems (STAP, 2011). Along with chemical pollutants such as heavy metals, nutrients, and hydrocarbons, marine debris contaminates beaches, surface, water column and seabed levels of the oceans worldwide. Marine debris consists of items of synthetic organic polymers, called "plastics", wood, metal, glass, rubber, clothing and paper.

The research data on marine debris show that plastics make up most of the marine debris, its proportion varying between 60\% and 80\% (Derraik, 2002). Substantial quantities of plastics have accumulated in the marine environment since the first reports of plastics occurrence in the early 1970s (Moore, 2015). Despite global efforts to reduce inputs and remove plastics from the marine environment, their abundance will increase due to resilience to environmental degradation and they will continue to 
exert a detrimental impact on marine biota, pose a navigational hazard for shipping, and cause negative economic and financial impacts to fishing, transportation and tourism, as well as governments and local communities (STAP, 2011).

The shipping industry contributes to global efforts to tackle the plastic pollution problem. Historically, ships were a major source of plastic pollution of the sea due to the maritime tradition of dumping garbage at sea (Hagen, 1990). For example, merchant ships were estimated to deposit 639,000 plastic containers daily worldwide in 1982 (Horsman, 1982). In response to global concerns about marine pollution, the International Marine Organization (IMO) in 1973 adopted the International Convention for the Prevention of Pollution from Ships, known as MARPOL 73/78, which has been amended by the Protocols of 1978 and 1997 (IMO, 2015a). MARPOL, primary international regime aimed at preventing and minimizing accidental pollution and pollution from routine operations on board ships entered into force in 1983. Annex $\mathrm{V}$ of the MARPOL Convention addresses garbage and its management and disposal. Despite the fact that the Annex V is optional ${ }^{1}$, it did receive a sufficient number of ratifications and has entered into force on 31 December 1988. Since then, a number of areas for its amendment have been recognised (IMO, 2011). The revised Annex V came into force on 1st January 2013.

The article is organised as follows. The second section covers sources, fate and environmental effect of plastics. The third section addresses measures for reducing the input of plastic debris. The conclusions are presented in the final section.

\section{Marine pollution and environmental toll of plastics}

With continuous growth since 1950, global annual production of plastics rose to 299 million tons in 2013 (PlasticsEurope, 2015). The substitution of metal, glass, wood and textile by plastics and designing new materials with tailored properties has led to an exponential production and consumption of plastics throughout a wide range of products. Application sectors for the plastic industry include packaging, building and construction, automotive, electrical and electronic, agriculture, household appliances, sport, health. Many plastic products are discarded after short period of usage (Hopewell et al., 2009). In spite of the global efforts to improve plastic waste management, a significant proportion of plastic products ends up in the oceans. Jambeck et al. calculated that out of 275 million metric tons of plastic waste generated in 192 coastal countries in 2010, 4.8 to 12.7 million metric tons entered the ocean contributing to accumulated debris (Jambeck et al., 2015).

$1 \quad$ Whilst Annexes I and II, dealing with oil and bulk noxious liquid substances respectively, are mandatory, Annexes III, IV, V and VI, dealing respectively with harmful substances in packaged forms, sewage, garbage, and air pollution are optional and as such may come into force at different time. 
Sources of plastic pollution are land-based (around $80 \%$ ) and marine-based (around $20 \%$ ) (STAP, 2011). Shipbuilding and ship recycling activities contribute to the inputs of plastic litter along with river discharge, industrial discharge, sewage, urban discharge and dumpsites, and littering by beachgoers. The quantity of land-sourced plastics is predicted to increase by an order of magnitude by 2025 (Jambeck et al., 2015). Marinebased sources include cargo, recreational and military navigation, fishing activities, aquaculture facilities, oil and gas platforms, legal and illegal dumping. Large quantities of plastics may enter the sea during storms, tidal flooding and shipping accidents.

Regardless of origin, once in the marine environment, plastics will persist and accumulate (STAP, 2011). Lightness, strength, durability and buoyancy, properties that make plastics desirable for diverse applications, enable dispersing and vertical distribution within the upper water column. Plastics are transported by currents for variable distances till they are settled on the seafloor, from where they can eventually be resuspended by wave action and tidal currents and re-transported. The spatial and temporal dynamics of plastics depend on numerous factors including broad seasonal and local hydrological factors, coastline geography, system-entry sources (including shipping routes) (Possatto et al., 2015).

According to the estimates from 2014 based on research data for period 20072013 at least 5.25 trillion plastic particles of all sizes were floating at sea (Eriksen et al., 2014). Studies have shown that floating plastic debris gathers in the shipping lanes, around fishing areas and in oceanic convergence zones. An important disparity between global input and surface load of plastics has been observed, and possible sinks are yet to be determined (Cozar et al., 2014). It has been proposed that substantial quantities of plastics are locked up in ice based on research finding up to 234 plastic particles per cubic metre of Arctic sea ice (Obbard et al., 2014). Reported plastic concentrations in deep-sea sediments in the Atlantic Ocean, the Mediterranean Sea and Indian Ocean, which were up to 800000 particles per cubic metre, indicate that seabed could be another huge reservoir (Woodall et al., 2104).

While the many important questions on occurrence and fate of plastics in the marine environment are still to be answered, their deleterious ecological consequences are well established. As a result of numerous studies performed during past five decades, a number of detrimental effects of plastics on the marine environment have been recognised. Marine organisms are injured or killed by ingestion and/or entanglement. A literature review published in 2015 showed that 30,896 individuals from 243 species have been reported to suffer from entanglement and 13,110 individuals from 208 species have been affected by ingestion of marine debris, most commonly by plastics (92\%) (Gall and Thompson, 2015). The list of species that have been reported includes seabirds, marine mammals, fish and crustaceans. Death by drowning, suffocation, strangulation, starvation through reduced feeding efficiency, reproductive failure and injuries are caused by fishing gear (rope, netting, lines, pots), intact items and packaging, fragments $>5 \mathrm{~mm}$, and microplastics, plastic particles $<5 \mathrm{~mm}$ (in some research areas research groups define microplastics as particles less than $1 \mathrm{~mm}$ in size 
(Gall and Thompson, 2015; Lusher et al., 2014). Discarded and lost fishing gear can continue to function as fishing apparatus for target fish and other species (referred to as ghost fishing) for lengthy periods of time. Drift plastics provide new surfaces for colonisation by microorganisms and macrobiota and influence the relative abundance of organisms within local assemblages. Furthermore, it has been reported that alien invasive species hitch-hike on floating items (Gall and Thompson, 2015). Possible harmful impacts of plastics also include chemical and physical pollution by passive litter on the seafloor, anoxia and hypoxia due to the blanketing effect, and creation of artificial hardgrounds (Gregory, 2009). Derelict fishing gear causes damage to coral reefs when nets or lines get snagged by the reef and break it off. Additional problems related to plastics are toxic, non-polymeric plastic additives (e.g. phtalates, bisphenol A, polybrominated diphenyl ethers) and toxicants such polychlorinated biphenyls (PCBs), organochlorines, polycyclic aromatic hydrocarbons (PAHs) and DDTs sorbed from the surrounding seawater (Mizukawa et al., 2013; Tanaka et al., 2013).

Recently, a significant concern regarding the risks to the marine ecosystem is caused by the ubiquitous presence of microplastics (Ivar do Sul and Costa, 2014). They are found in rivers, estuaries, coastal waters, surface waters, throughout the water column, sediments, and marine organisms (Rocha-Santos and Duarte, 2015). Microplastics can be classified into two groups: primary are those produced for usage for specific purposes, such as abrasive scrubbers or cosmetics and secondary are fragments and fibers produced through degradation of larger plastic items by mechanical, chemical and biological processes (Rocha-Santos and Duarte, 2015; Van Cauwenbeghe and Janssen, 2014). Distinctive properties of microplastics such as size, shape, density, colour, and abundance determine their distribution in the environment and bioavailability to organisms. A further research is required to understand the fate of microplastics and related organic pollutants in the marine environment. There is a need for development of analytical methods for quantitative and qualitative analysis of chemical compounds derived from microplastics. Furthermore, there is a gap of knowledge that is needed to be addressed regarding their ecological harm. Studies have shown that ingesting microplastics directly or indirectly causes physical harm and transport organic pollutants to marine biota (Teuten et al., 2009).

Small dimensions of microplastics enable ingestion by an array of marine organisms, at various trophic levels. Therefore, ingested microplastics are entering the food chain, thus raising a question about human food safety (Van Cauwenbeghe and Janssen, 2014). A study performed on commercially grown mussels and oysters showed that European shellfish consumers could ingest up to 11000 microplastic particles per year. A comparison between farmed and wild mussels determined that significantly more microplastics were present in farmed mussels (Mathalon and Hill, 2014). It is known that monomers and additives leaching from microplastics can cause a number of adverse human health effects, including reproductive abnormalities (Rochman et al., 2013). Despite the growing body of research, there is still a lack of data on the toxicity of microplastics in humans. 


\section{Prevention of plastic pollution from ships}

There are a number of global, international and national legal, regulatory and management initiatives aimed at the prevention and management of marine debris. MARPOL is one of the most important global legal instruments. With 153 signatories, it currently regulates more than $98 \%$ of the world's shipping tonnage $(98.52 \%$ on 15 July 2015) (IMO, 2015b). Annex V, which deals with garbage pollution from ships and mineral resource platforms at sea, was the first of the optional MARPOL Annexes that has entered into force. 147 nations, representing $98.03 \%$ of world tonnage have ratified Annex V, including the main flags of convenience Panama, Liberia and Honduras (IMO, 2015b). States party to MARPOL that have not ratified Annex V as of 14 July 2015 are Brunei Darussalam, Cook Islands, Djibouti, Myanmar, Seychelles and Thailand. Annex $\mathrm{V}$ provides the framework for the control of garbage generated by all ships and offshore platforms, both fixed and floating (IMO, 2011). Unlike discharge of some other types of ship-generated wastes such as paper, rags, glass, metal, crockery, which was permitted outside special areas ${ }^{2}$ at defined distances from the nearest land by the previous version of Annex $\mathrm{V}$, and it is prohibited by the revised version, discharge of plastics has been prohibited by both versions. Beside plastics used or present on board ships (packaging items, parts of ship construction, disposable eating utensils, bags, sheeting, floats, fishing nets, fishing lines, rope, sails and many other plastic items) revised Annex V also prohibits discharge of incinerator ashes from plastic products. Exemptions apply only in limited situations when discharge of garbage/fishing gear is necessary for the purpose of securing the safety of a ship and those on board or saving life at sea, or when accidental loss of fishing gear or garbage resulting from damage to a ship or its equipment occur, provided that all reasonable precautions were taken (IMO, 2012). For such discharges, entries into the Garbage Record Book (GRB), or the ship's official log-book for ships of less than $400 \mathrm{GT}$ are required.

Regarding documents that must be carried onboard Annex $V$ imposes the following requirements:

(a) Every ship of 100 GT and above (instead of 400 GT required by the superseded Annex V), and every ship which is certified to carry 15 or more persons, and fixed or floating platforms must carry a garbage management plan, (GMP) (based on IMO Guidelines MEPC.220(63) and in working language of the crew) containing procedures for minimizing, collecting, storing, processing and disposing of garbage, including the use of the equipment on board.

(b) Every ship of 400 GT and above, and every ship certified to carry 15 persons or more engaged in voyages to ports or offshore terminals under the jurisdiction of other Parties to Annex V, and every fixed or floating platform must carry and maintain a GRB.

\footnotetext{
2 The special areas under Annex V are the Mediterranean Sea area, the Baltic Sea area, the Black Sea area, the Red Sea area, the Gulfs area, the North Sea area, the Antarctic area and the Wider Caribbean Region
} 
Beside accidental or other exceptional discharges or loss of garbage, entries in the GRB are made in cases of discharges to reception facilities ashore or to other ships, incineration, and discharges into the sea in accordance with regulations 4, 5 or 6 of Annex V. Date and time of discharge or incineration, position of the ship, port or facility or name of ship, and estimated amount of garbage have to be recorded.

GRB and GMP facilitate enforcement and control of Annex V regulations. Namely, GRB and GMP are subject to examination by Port State Control Officers during inspections to verify compliance with Annex V. If over-viewing of the GRB and/or GMP shows that the ship had disposed of garbage in violation of Annex V or other significant deficiency (e.g. GRB does not comply with requirements indicating that key crew members on board are not familiar with requirements to the categorizing or the disposal of garbage) ship can be detained.

However, Annex V fails to impose recordkeeping requirements for the handling of garbage for ships under 400 GT. This means that most of the global fishing fleet is not required to record discharge operations (Chen and Liu, 2013). This gap in the control could be one of the reasons why fishing vessels often discharge plastic debris into sea (Chen and Liu, 2013; Jones, 1995; Topping et al., 1997). A study conducted in 1990-1991, after Annex V came into force, showed that 75.2\% observed fishing vessels operating along Canada's east coast threw debris into sea (Topping et al., 1997). Furthermore, because it is difficult to detect violations at sea and often impossible to link debris with a particular ship, legislation is often ignored by other types of vessels and shipping still significantly contributes to plastic pollution (Clark, 1997; Hagen, 1990; Topçu et al., 2013, Tubau et al., 2015). For example, research conducted from 1982 to 1998 found that quantity of debris around the northwestern Hawaiian Islands has not decreased due to implementation of Annex V. Recently, some plastic debris sampled during 2013 in the Paranagua Estuarine Complex, a World Heritage Listed Brazilian estuary, originated from passing ships (Possatto et al., 2015).

Additionally, some reported cases of violation of Annex V remain unpunished (Hagen, 1990). Namely, beside the port State jurisdiction, MARPOL bestows the flag State jurisdiction. The flag state is under the obligation to investigate cases of ship's violation of the Annex V. However, it seems that flag states fail to exercise effective jurisdiction.

Because it is difficult to accomplish direct enforcement of Annex $\mathrm{V}$ regulations, other measures to reduce plastic pollution are very important. Environmental education is one of the tools to address the problem (GESAMP, 2015). Raising awareness of the detrimental consequences of operational or accidental pollution of the marine environment is needed to alter disposal practices. Therefore, the Seafarers Training, Certification, \& Watchkeeping (STCW) Code requires that maritime officers gain knowledge on the prevention of pollution to the marine environment. In 2011, the IMO accepted the model course "Marine Environmental Awareness", which is developed to give knowledge on the concept of sustainable shipping, complexity and diversity of the marine environment, impact of shipping on the environment, role of regulations, 
procedures and technical installations to protect the environment, marine environmental awareness, personal responsibility and role of human element to prevent pollution, proactive measures (IMO 2015c). Environmental education programs are especially important as part of lifelong learning for masters, since they can promote positive behaviour change among crew members (Chen and Liu, 2013).

Ship passengers have a significant role in protecting marine habitats and it is important to raise their awareness about plastic pollution. A challenge for policy makers is to communicate environmental information in a way that will affect their disposal practices. The fact that plastics may exert the adverse impacts on human health could be used to increase concern about incidence of plastic in the marine environment and support for marine policy. Namely, research on climate change communication have shown that framing climate change in terms of public health instead of environmental problem is more effective at engaging audiences (Myers et al., 2012; Nisbet, 2009). Similarly, it has been shown that messages focusing on public health consequences of marine disease resonate more than messages focusing on marine organism health (McComas et al., 2015).

\section{Conclusion}

A plethora of research exists which highlights the damaging impacts of plastic pollution on the marine environment. However, after almost 50 years of research, many questions about the distribution, fate and behaviour of plastics, particularly microplastics are yet to be answered. Key knowledge gaps include estimations of the potential risks for human health.

Despite the commitment of shipping industry to reduce marine littering, regulatory requirements are not always followed uniformly and discharge violations under Annex V occur. Legislation alone is not sufficient and enhancement of environmental awareness through education is necessary in order to reduce the input of plastics to the marine environment. Gathering information on attitudes and motives for plastic disposal practices of seafarers could help to develop programmes targeted at shipping.

\section{References}

1. Chen, C-L., Liu, T-K. 2013. Fill the gap: Developing management strategies to control garbage pollution from fishing vessels, Marine Policy 40: 34-40.

2. Clark, R. B. 1997. Marine Pollution. Clarendon Press, Oxford.

3. Cozar, A.; Echevaria, F.; Gonzalez-Gordillo, J. I.; Irigoien, X.; Úbeda, B.; Hernandez-Leon, S.; Palma, A. T.; Navarro, S.; García-de-Lomas, J.; Ruis, A.; Fernandez-de-Puelles, M. L.; Duarte, C. M. 2014. Plastic debris in the open ocean, Proceedings of the National Academy of Sciences 111: 10239-10244.

4. Derraik, J. G. B. 2002. The pollution of the marine environment by plastic debris: A review, Marine Pollution Bulletin 44(9): 842-852.

5. Eriksen, M.; Lebreton, L. C .M.; Carson, H. S.; Thiel, M.; Moore, C. J.; Borerro, J. C.; Galgani, F.; Ryan, P. G.; Reisser, J. 2014. Plastic pollution in the world's oceans: more than 5 trillion pla- 
stic pieces weighing over 250,000 tons afloat at sea, PLoS One 1-15. http://dx.doi.org/10.1371/ journal.pone.0111913.

6. Gall , S. C; Thompson, R.C. 2015. The impact of debris on marine life, Marine Pollution Bulletin 92: $170-179$.

7. GESAMP, 2015. Sources, fate and effects of microplastics in the marine environment: a global assessment, Kershaw, P. J.; ed. (IMO/FAO/UNESCO-IOC/UNIDO/WMO/IAEA/UN/UNEP/ UNDP Joint Group of Experts on

8. the Scientific Aspects of Marine Environmental Protection). Rep. Stud. GESAMP No. 90, 96 p.

9. Gregory, R. M. 2009. Environmental implications of plastic debris in marine settings-entanglement, ingestion, smothering, hangers-on, hitch-hiking and alien invasions, Philosophical Transactions of the Royal Society B 364: 2013-2025.

10. Hagen, P. E. 1990. The International Community Confronts Plastics Pollution from Ships: MARPOL Annex V and the Problem That Won't Go Away, American University International Law Review 5(2): 425-496.

11. Henderson, J. R. 2001. A Pre- and Post-MARPOL Annex V Summary of Hawaiian Monk Seal Entanglements and Marine Debris Accumulation in the Northwestern Hawaiian Islands, 1982-1998, Marine Pollution Bulletin 42(7): 584-589.

12. Horsman, P.V. 1982. The amount of garbage pollution from merchant ships, Marine Pollution Bulletin 13: 167-169.

13. IMO, 2011. Amendments to the Annex of the Protocol of 1978 Relating to the International Convention for The Prevention of Pollution from Ships, 1973. (Revised MARPOL Annex V). MEPC.201(62)

14. IMO, 2012. 2012 Guidelines for the Implementation of MARPOL Annex V. MEPC.219(63)

15. IMO, 2015a. List of conventions and their amendments. Available from Internet: http://www. imo.org/en/About/Conventions/StatusOfConventions/Documents/List $\% 20$ of $\% 20$ instruments $\% 20$ as\%20at $\% 2018 \% 20$ June $\% 202015$.pdf

16. IMO, 2015b. Summary of Status of Conventions. Available from Internet: http://www.imo.org/ en/About/Conventions/StatusOfConventions/Pages/Default.aspx

17. IMO, 2015c. List of IMO Model courses. Available from Internet: http://www.imo.org/en/ OurWork/HumanElement/TrainingCertification/Documents/list\%20of\%20IMO\%20Model\%20 Courses.pdf

18. Ivar do Sul, J. A.; Costa, M. F. 2014. The present and future of microplastic pollution in the marine environment, Environmental Pollution 185: 352-364.

19. Jambeck, J. R.; Geyer, R.; Wilcox, C.; Siegler, T. R.; Perryman, M.; Andrady, A.; Narayan, R.; Law, K. L. 2015. Plastic waste inputs from land into the ocean, Science 347: 768-771. http:// dx.doi.org/10.1126/science. 1260352

20. Jones, M. M. 1995. Fishing debris in the Australian marine environment, Marine Pollution Bulletin 30: 25-33.

21. Leite, A.S.; Santos, L. L.; Costa, Y.; Hatje, V. 2014. Influence of proximity to an urban center in the pattern of contamination by marine debris, Marine Pollution Bulletin 81: 242-247. http:// dx.doi.org/10.1016/j.marpolbul.2014.01.032.

22. Lusher, A. L.; Burke, A.; O'Connor, I.; Officer, R. 2014. Microplastic pollution in the Northeast Atlantic Ocean: Validated and opportunistic sampling, Marine Pollution Bulletin 88(1-2): 325-333.

23. Mathalon, A.; Hill, P. 2014. Microplastic fibers in the intertidal ecosystem surrounding Halifax Harbor, Nova Scotia, Marine Pollution Bulletin 81: 69-79. http://dx.doi.org/10.1016/j.marpolbul.2014.02.018.

24. McComas, K. A.; Schuldt, J. P.; Burge, C. A. ; Roh, S. 2015. Communicating about marine disease: The effects of message frames on policy support, Marine Policy 57: 45-52.

25. Mizukawa, K.; Takada, H.; Ito, M.; Geok, Y.B.; Hosoda, J.; Yamashita, R.; Saha, M.; Suzuki, S.; Miguez, C.; Frias, J.; Antunes, J. C.; Sobral, P.; Santos, I. R.; Micaelo, C.; Ferreira, A. M. 2013. Monitoring of a wide range of organic micropollutants on the Portuguese coast using plastic resin pellets, Marine Pollution Bulletin 70, 296-302.

26. Moore, C. J. 2015. How much plastic is in the ocean? You tell me! Marine Pollution Bulletin 92: $1-3$.

27. Myers, T.; Nisbet, M. C.; Maibach, E. W.; Leiserowitz, A. 2012. A Public Health Frame Arouses Hopeful Emotions about Climate Change, Climatic Change 113: 1105-1112. 
28. Nisbet, M. C. 2009. Communicating climate change: why frames matter for public engagement, Environment: Science and Policy Sustainable Development 51: 12-23.

29. Obbard, R. W.; Sadri, S.; Wong, Y. Q.; Khitun, A. A.; Baker, I, Thompson R. C. 2014. Global warming releases microplastic legacy frozen in Arctic Sea ice, Earth's Future 2: 315-320. doi:10.1002/2014EF000240

30. PlasticsEurope 2015. Plastics - the Facts 2014. An analysis of European plastics production, demand and waste data. Available from Internet: http://www.plastval.pt/conteudos/File/Publicacoes/ Plastics\%20-\%20the\%20Facts\%202014.pdf

31. Possatto, F.E.; Spach H. L.; Cattani, A.P.; Lamour, M. R.; Santos, L. O.; Cordeiro, N.M.; Broadhurst, M. K. 2015. Marine debris in a World Heritage Listed Brazilian estuary, Marine Pollution Bulletin 91(2):548-53.

32. Tanaka, K.; Takada, H.; Yamashita, R.; Mizukawa, K.; Fukuwaka, M.; Watanuki, Y. 2013. Accumulation of plastic-derived chemicals in tissues of seabirds ingesting marine debris, Marine Pollution Bulletin 69: 219-222.

33. Teuten, E. L.; Saquing, J. M.; Knappe, D. R. U.; Barlaz, M. A.; Jonsson, S.; Bjorn, A.; Rowland, S. J.; Thompson, R. C.; Galloway, T. S.; Yamashita, R.; Ochi, D.;Watanuki, Y.; Moore, C.; Pham, H. V.; Tana, T. S.; Prudente, M.; Boonyatumanond, R.; Zakaria, M.P.; Akkhavong, K.; Ogata, Y.; Hirai, H.; Iwasa, S.; Mizukawa, K.; Hagino, Y.; Imamura, A.; Saha, M.; Takada, H. 2009. Transport and release of chemicals from plastics to the environment and to wildlife, Philosophical Transactions of the Royal Society B: Biological Sciences 364: 2027-2045.

34. Topçu, E. N.; Tonay, A.M.; Dede, A.; Öztürk, A.A.; Öztürk, B. 2013. Origin and abundance of marine litter along sandy beaches of the Turkish Western Black Sea Coast, Marine Environmental Research, 85: 21-28.

35. Topping, P.; Morantz, D.; Lang, G. 1997. Waste disposal practices of fishing vessels: Canada's east coast, 1990-1991, in: Coe, J.M.; Roger, D.B. (Eds.). Marine debris: sources, impacts, and solutions, NY: Springer, 253-262.

36. Tubau, X.; Canals, M.; Lastras, G.; Rayo, X.; Rivera, J.; Amblas, D. 2015. Marine litter on the floor of deep submarine canyons of the Northwestern Mediterranean Sea: The role of hydrodynamic processes, Progress in Oceanography 134: 379-403. 10.1016/j.pocean.2015.03.013

37. Rocha-Santos, T.; Duarte, A. C. 2015. A critical overview of the analytical approaches to the occurrence, the fate and the behavior of microplastics in the environment, Trends in Analytical Chemistry $65:$ 47-53

38. Rochman, C.M.; Browne, M. A.; Halpern, B. S.; Hentschel, B. T.; Hoh, E.; Karapanagioti, H. K.; Rios-Mendoza, L. M.; Takada, H.; Teh, S.; Thompson, R. C. 2013. Policy: classify plastic waste as hazardous, Nature 494: 169-171.

39. STAP (2011). Marine Debris as a Global Environmental Problem: Introducing a solution based framework focused on plastic. A STAP Information Document. Global Environment Facility, Washington, DC. Available from Internet: http://www.thegef.org/gef/sites/thegef.org/files/publication/STAP\%20MarineDebris\%20-\%20website.pdf

40. Van Cauwenberghe, L.; Janssen, C. R. 2014. Microplastics in bivalves cultured for human consumption, Environmental Pollution 193: 65-70.

41. Woodall, L.C.; Canals, M.; Paterson, G. L. J.; Coppock, R.; Sleight, V.; Calafat, A.; Rogers, A. D.; Narayanaswamy, B. E.; Thompson, R. C. 2014. The deep sea is a major sink for microplastic debris, Royal Society Open Science 1: 140317. http://dx.doi.org/10.1098/rsos.140317 
Jelena Čulin, Toni Bielić

\section{Onečišćenje plastikom sa brodova}

\section{Sažetak}

Utjecaj pomorskog prometa na morski okoliš uključuje ispuštanje otpada. Plastični otpad je posebno problematičan zbog velikih količina, otpornosti na degradaciju i štetnog učinka na morsku biotu. Prema nedavno objavljenim studijama, daljnja istraživanja su potrebna za procjenu rizika za ljudsko zdravlje. Praćenje stanja ukazuje da je unatoč zabrani ispuštanja u more, pomorski promet i dalje izvor onečišćenja plastičnim otpadom. U radu se raspravlja o pojedinim mjerama za rješavanje problema.

Ključne riječi: onečišćenje plastikom, morski okoliš, MARPOL 73/78 Annex V, obrazovanje, svijest o okolišu 